\title{
SIGNIFIKANSI MAQÂSID AL-SHARI'AH SEBAGAI KERANGKA BERPIKIR EPISTEMIK IJTIHAD
}

\author{
Sanuri \\ Universitas Islam Negeri Sunan Ampel Surabaya, Indonesia \\ E-mail: sun_76@yahoo.com
}

\begin{abstract}
This paper focuses on the importance of maqâsid al-shari' $a$ h for the effectiveness of ijtihad in Islamic law. The emergence of controversies at the beginning of the tenth century $\mathrm{AD}$ on the issue of the closing of the gate of ijtihâd has resulted in the rigidity of Islamic law and its methodological framework. Along with these issues, some contemporary scholars on maqâsid agreed that sharî'ah law (alQur'ân) consists of partial (juz'ŷyât) and universal values (kulliyyât) that should be understood through a holistic approach in the frameworks of maqâsid. Shift in the meaning and orientation of maqâsid al-sharîah in some contemporary Muslim scholars' views, involving social sciences, philosophy of law, principles of morality, universality, social justice, human dignity, human rights, is a concrete manifestation of how Islamic law is able to provide answers to the current problems faced by the Muslim and non-Muslims community. This awareness has made contemporary Muslim thinkers strive to bring Islamic law into various achievements of progress in many aspects of life by emphasizing the importance of maqâsid al-sharîah.
\end{abstract}

Keywords: Maqâsid al-sharîah, istiqrâ', ijtihad.

\section{Pendahuluan}

Saat ini, maqâsid al-sharîah adalah tema yang cukup menarik seiring dengan munculnya para sarjana kontemporer yang memiliki perhatian khusus terhadap perkembangan hukum Islam. Semangat yang menjadi titik tolak untuk menjadikan hukum Islam mampu berselaras dengan berbagai perubahan adalah karena Islam adalah agama yang rabmah li al-âlamin ${ }^{1}$ dan pengadaptasian Islam untuk setiap kurun waktu dan

1 Raḥmah li al-âlamîn, dalam konteks sharî‘ah, menurut Aḥmad al-Raysûnî adalah bahwa seluruh ketentuan sharî‘ah pasti mengandung 'illah dan hikmah. Dari kedua unsur itu pasti berdimensi maslahat bagi kehidupan manusia di dunia dan akhirat. 
tempat yang berbeda. Pun Islam sangat menjunjung tinggi nilai-nilai keadilan, kebebasan, persamaan derajat (al-musâwâh), kebijaksanaan, dan kebaikan manusia (mașlaḥat al-íbâd).

Beranjak dari nilai-nilai filosofis di atas, maka semua perbedaan pandangan tentang dimensi agama Islam mulai dari akhlaq, aqidah, ibadah, dan mu'amalah yang bersifat parsial dapat dipahami dan diintegrasikan melalui nilai-nilai universal. Semangat universalitas itulah yang mengilhami para ulama pembaru klasik sampai kontemporer untuk tetap menjaga elastisitas hukum Islam agar tetap bisa berkorespondensi dengan berbagai perubahan sosial dan perkembangan peradaban manusia. ${ }^{2}$ Akan tetapi banyak kalangan yang menyayangkan prestasi gemilang para ulama lampau yang telah mampu mencairkan kebekuan hukum Islam menjadi sebuah tatanan hukum yang elastis dan dinamis pada satu sisi, dan produktivitas para ulama pada sisi lain, dikejutkan oleh adanya pernyataan kontroversial tentang isu the closing of the gate of ijtihad (pintu ijtihad tertutup). Terlepas dari benar atau salah isu kontroversial ini, jelasnya stagnansi progresivitas bangunan epistemologi, metodologi, dan kebekuan hukum Islam mulai dari pertengahan abad ke-14 M., yakni periode alShâtibî (w. 790 H/1388 M), sampai saat ini dimungkinkan memiliki keterkaitan baik secara langsung maupun tidak langsung dengan isu yang muncul sejak awal abad ke-10 Masehi kala itu. ${ }^{3}$

Sejalan dengan perubahan waktu, umat Islam dihadapkan pada kompleksitas dalam segala lini kehidupan, maka ijtihad dalam hukum Islam sangat diperlukan termasuk inovasi-inovasi metodologis. Landasan epistemologi istinbât hukum yang diusung oleh para ulama usûl, baik klasik maupun kontemporer, adalah untuk merealisir satu kata kunci yaitu "kemaslahatan untuk manusia" (al-masâlị̣ li al-íbâd). Dalam bingkai semangat maslahah inilah para ulama usûl mulai mengaktualisir suatu instrumen metodologis berupa maqâsid al-sharî‘

Pendapat ini dikutip oleh Shams al-Dîn dalam mukaddimahnya. Lihat Muhammad Mahdî Shams al-Dîn, Maqâsid al-Sharî́ah (Damshiq: Dâr al-Fikr, 2001), 13.

${ }^{2}$ Malcolm H. Kerr, Islamic Reform: The Political and Legal Theories of Muhammad Abduh and Rashîd Ridâa (California: University of California Press, 1966), 55; Albert Hourani, Arabic Thought in the Liberal Age 1798-1939 (Cambridge: Cambridge University Press, 1983), 150.

${ }^{3}$ Salih Kesgin, "A Critical Analysis of the Schacht's Argument and Contemporary Debate on Legal Reasoning Throughout the History of Islamic Jurisprudence", The Journal of International Social Research, Vol. 4, No. 19 (2011), 158. 
(tujuan-tujuan sharî‘ah), biikmat al-sharîab (hikmah sharî‘ah), asrâr alsharíah (rahasia-rahasia sharî‘ah), dan mahâasin al-sharî'ab (keindahankeindahan sharî‘ah). ${ }^{4}$ Inilah paradigma baru dalam rangka revitalisasi dan kontekstualisasi (min al-nâșs ilâ al-wâqi-meminjam istilah Ḥasan Hanafí-hukum Islam yang diharapkan mampu berinteraksi secara intens dengan nilai-nilai modernitas melalui proses ijtihad.

\section{Definisi Maqâșid al-Sharî‘ah}

Secara etimologis maqậid al-sharî́ah tersusun dari dua kata, maqậid dan sharîhah. Maqâsid adalah bentuk jamak dari kata qaș yang berarti 'bermaksud', 'menuju suatu tujuan', 'tengah-tengah', 'adil dan tidak melampaui batas', 'jalan lurus'. Interpretasi ini sejalan dengan potongan ayat dalam Q.S. Luqmân [31]: 19 ... waqsid fì mashyik ${ }^{6}$ (... dan sederhanakanlah kamu dalam berjalan). Tâha 'Abd Rạ̣mân mengatakan bahwa kata maqsid memiliki tiga makna, yaitu: (1) ḅusûl alfawâid (mendapatkan manfaat); (2)ḥusûl al-tawajjuh wa al-khurûj min alnisyân (semakin menjauh dari sifat lupa); dan (3) ḅusûl al-ghard al-șahîh. wa qiyâm al-bâith (menuju tujuan yang benar dengan menjalankan apa yang disharî́ahkan). ${ }^{7}$ Dari berbagai definisi kebahasaan yang beragam di atas, apa yang dikehendaki oleh para maqâsidîyun dengan kata almaqâsid adalah al-hadaf (arah), al-ghâyah (tujuan akhir), al-istiqâmah (tetap/konsisten), al-'adl (adil), al-i'tidâl (moderat), mâ warâ' al-fíl (sesuatu yang dituju di balik perbuatan), dan al-ghâyah min al-ạ̣kâm alIslâmîyah (tujuan dari hukum-hukum dalam Islam). ${ }^{8}$

Sedangkan unsur kedua adalah kata sharíah. Kata ini berasal dari shara' yang berarti 'jalan menuju mata air', kebiasaan atau sunnah.

\footnotetext{
${ }^{4}$ Sayyid b. Husayn al-'Affânî, Zahr al-Basâtîn min Mawâqif al-'Ulamâ' wa al-Rabbâniyyîn, Vol. 5 (Kairo: Dâr al-'Affânî, t.th.), 105.

${ }^{5}$ Fayrûz Abadî, al-Qâmûs al-Muhît (Beirut: Muassasat al-Risâlah, 1987), 396.

6 Selain makna di atas, kata qasd juga berarti adil ('ad), atau sikap pertengahan (itidâh), yaitu kebalikan dari sikap melampaui batas (ifrât), seperti sikap pertengahan antara boros (isrâf) dan kikir (taqtîr).

7 Aḥsan Lihasâsanah, al-Figh al-Maqậsid ind al-Imâm al-Shâtibî wa Atharub 'alâ Mabâhith Ușûul al-Tashrî al-Islâmî (Kairo: Dâr al-Salâm li al-Tibâ'ah wa al-Nashr wa alTawzî' wa al-Tarjamah, 2008), 11-12. Lihat juga Tâha 'Abd Raḥmân, Tajdîd alManhaj fî Taqwîm al-Turâth (Beirut: al-Markaz al-Thaqâfî al-'Arabî, 1994), 98.

${ }^{8}$ Muḥammad Tâhir b. 'Âshûr, Maqậsid al-Sharîah al-Islâmîyah, ed. Muhammad alTâhir al-Mîsâwî (Kuala Lumpur: al-Fajr, 2001), 183. Lihat juga Jasser Auda, Maqâạid al-Sharíab: Dalîl li al-Mubtadi' (London: International Institute of Islamic Thought, 2008), 15.
} 
'Jalan', secara etimologis berarti al-tarígah, yaitu jalan yang ditempuh menuju sumber air untuk diminum. Menurut 'Izz al-Dîn b. 'Abd alSalâm (w. 660 H/1209 M) secara terminologis, kata sharî‘ah dimaknai jalan yang lurus dan aturan hukum yang diridai Allah bagi hambaNya". Lebih ringkas, "Alî al-Tahânawî mendefinisikan sharî‘ah sebagai "efek perintah dalam bentuk pembebanan berupa "ubudîyab". Sharî‘'ah juga diartikan "menuju ke arah sumber pokok keadilan". ${ }^{10}$ Kamâl Hạîib mendefinisikan sharî́ah dengan "jalan lurus yang harus ditempuh agar manusia mendapatkan keselamatan di dunia dan akhirat", sebagaimana dalam Q.S. al-Jâthiyah [45]: 18 yang artinya "kemudian Kami jadikan kamu berada di atas suatu sharî‘ ah dari urusan itu, maka ikutilah sharî‘'ah itu dan janganlah kamu ikuti hawa nafsu orang-orang yang tidak mengetahui" dan Q.S. al-Mâidah [5]: 48 yang artinya "bagi tiap-tiap umat di antara kamu, Kami berikan aturan dan jalan yang terang". "Al-Raysûnî mengatakan bahwa sharî‘ah bermakna "ketentuan hukum Islam yang bersifat praktis dalam bentuk konsepsi aqidah, legislasi, akhlaq, maupun mu'ámalab". ${ }^{12} \mathrm{Dalam}$ konteks fiqh, sharî̀'ah diartikan "hukum-hukum yang disharî‘atkan Allah untuk hamba-Nya, baik berupa ketentuan yang bersumber dari al-Qur'ân atau Sunnah".

Dengan demikian, maqâasid al-sharíah memiliki beragam padanan kata. Ulama uș̂l al-fiqh, al-Shâtịîi, sering menggunakan beberapa istilah seperti kata maqâsid al-sharîah (tujuan-tujuan hukum), ${ }^{14}$ almaqâsid al-sharîyah fì al-sharîah (tujuan hukum yang terdapat dalam

\footnotetext{
${ }^{9}$ Muḥammad 'Alî al-Tahânawî, Mawsî̀'ah Kashshâf Istilâhât al-Funûn wa al-'Ulûm, Vol. 1, ed. 'Alî Dahrûj (Beirut: Maktabat Lubnân, 1996),1019.

${ }^{10}$ Louis Ma'luf, al-Munjid fî al-Lughah wa al-A lâm (Beirut: Dâr al-Mashrîq, 1986), 632. Yûsuf 'Ali dan Muhammad Hashîm Kamâlî menganggap penting untuk membedakan sharî́ah dan fiqh di mana sharî‘ah adalah berupa ketentuan-ketentuan hukum yang terdapat dalam al-Qur'ân dan hạaith. Sedangkan, fiqh adalah kreasi dari hasil pemahaman manusia (buman cognitive). Lihat Nias A. Shah, Islamic Law and the Law of Armed Conflict: The Armed Conflict in Pakistan (New York: Routledge, 2011), 12-13.

${ }^{11}$ Kamâl Hạâib, Tạnawwulât al-Ḥarakah al-Islâmîyah wa al-Istirâjîyah al-Amrikîyah (t.t.: Kutub 'Arabîyah, 2001), 12.

12 'Abd al-Wahhâb Khalaf, 'Im Usûl al-Fiqh (Kairo: Dâr al-Quwaytîyah, 1968), 32.

13 al-Qur'ân, 42: 13; al-Qur'ân 45: 18. Lihat juga penjelasan yang diberikan oleh Fazlur Rahman, Islam (Chicago: University of Chicago, 1979), 108.

14 Abû Ishâaq al-Shâtibî, al-Muwâfaqât fî Uṣ̂l al-Ạ̣kâm, Vol. 1, ed. Muhammad alKhadar Husein al-Tûlisî (t.t.: Dâr al-Fikr, t.th.), 4-5.
} 
hukum sharî́ah), ${ }^{15}$ dan maqậid min shar' al-ḅukm (tujuan disharî‘ahkannya hukum Islam). Muhammad Tâhir b. 'Âshûr mengartikan bahwa maqâsid al-sharîa adalah "maksud dan hikmah yang dikehendaki pembuat sharî̀ah dalam segala ketentuan sharî‘ahNya untuk menunjukkan keunggulan (magnimity) hukum-hukum sharî'ah yang tidak ditampakkan pada kasus-kasus hukum tertentu". ${ }^{16}$

'Allâl al-Fâs11'(w. 1394 H/1974 M) mendefinisikan maqậid alsharíah dengan "tujuan-tujuan dan rahasia-rahasia yang dikehendaki oleh pembuat sharîah pada semua ketentuan hukum Islam". ${ }^{18}$ Menurut Aḥmad al-Raysûnî, maqâsịd al-sharîh adalah "tujuan yang selalu menempel pada hukum sharî́ah untuk kemaslahatan manusia". ${ }^{19}$ Yûsuf Hầmid al-“Âlim mendefinisikan bahwa maqậsid alshari"ah adalah "tujuan yang hendak dicapai oleh ketentuan hukum Islam dan rahasia-rahasia yang dikehendaki oleh pembuat sharî‘ yang Maha Bijaksana atas setiap ketentuan hukum". ${ }^{20}$ Sedangkan menurut Jasser Auda, maqâsid al-sharîah adalah "tujuan dan rahasia di balik ketentuan dan ketetapan hukum Islam". 21

15 Ibid., 7. Di kalangan para ulama uṣ̂l al-fiqh lainnya, maqâsid al-sharíah juga dipahami dengan asrâr al-sharíah, yaitu rahasia-rahasia yang terdapat di balik hukum yang ditetapkan oleh sharî́ah berupa kemaslahatan bagi umat manusia baik di dunia maupun di akhirat. Misalnya, sharî́ah mewajibkan berbagai macam ibadah dengan tujuan untuk menegakkan agama Allâh (hî̉ al aldîn), disharî‘atkan hukuman bagi pelaku zina untuk memelihara kehormatan dan kuturunan (bifzal-nash), disharî‘ahkan hukum tentang larangan pencurian untuk memelihara harta seseorang (hif za al-mâl), disharî‘ahkan hukuman qișâs untuk memelihara jiwa seseorang (hifžal-nafs).Maka dari itu, maqâsid al-sharíah dapat diartikan sebagai tujuan-tujuan yang hendak dicapai dari suatu penetapan hukum. Lihat Râid Naṣrî Jamîl Abû Mu'nas, Manhaj al-Ta'lîl bi alHịikmah wa Atharuh fî Tashrî al-Islâm: Dirâsah Ușûlîyah Tạ̣lîlîyah (Herndon: al-Ma'had al-'Âlimî li al-Fikr al-Islâmî/IIIT, 2007), 262.

16 'Allâl al-Fâsî, Maqâsid al-Sharî'ah al-Islâmîyah wa Makârimuhâ (Beirut: Maktabat alWaḥdah al-'Arabîyah, 1963), 51.

17 Nama lengkapnya adalah 'Allâl b. 'Abd Allâh al-Wâhịid b. 'Abd al-Salâm b. 'Allâl 'Abd Allâh al-Majdhûb al-Fâsî al-Fahrî (1326-1394 H/ 1910-1974 M).

18 Ibid., 3.

19 Aḥmad al-Raysûnî, Naærrîyat al-Maqậsid 'ind al-Shâtibî (t.t.: Maṭba'at al-Najâh alJadîdah, 1991), 7.

${ }^{20}$ Nûr al-Dîn Mukhtâr al-Khâdimî, Abḥâth fì Maqâsìi al-Sharî‘ (Beirut: Muassasat al-Ma'ârif li al-Tiibâ'ah wa al-Nashr, 2008), 14.

${ }^{21}$ Jasser Auda, Maqâsid al-Sharíah as Philosophy of Islamic Law: A Systems Approach (London: International Institute of Islamic Thought, 2008), 2. 
Dari berbagai definisi di atas, Nûr al-Dîn Mukhtâr al-Khâdimî menggarisbawahi beberapa komponen dasar yang harus ada dalam maqâsid al-sharí ah yaitu: (1) harus mengandung tujuan dan rahasia yang hendak dicapai; (2) hukum sharî‘ah; (3) semua tujuan dan rahasia yang dikehendaki harus bermuara pada nilai ketaatan atau 'ubûdîyah kepada Allah; dan (4) tujuan dan rahasia itu berupa maslahat bagi manusia di dunia dan akhirat". 22

Dalam pandangan beberapa sarjana Muslim kontemporer, definisi maqâsid al-sharíah mengalami pergeseran makna dan orientasi dengan melibatkan social sciences, filsafat hukum, dan lebih bercorak teoantroposentris daripada teosentris. Wahbah al-Zuhaylî mendefinisikan maqâșid al-sharîah dengan nilai-nilai dan sasaran hukum yang tersirat. Nilai-nilai dan sasaran-sasaran itu dipandang sebagai tujuan dan rahasia sharî'ah yang ditetapkan oleh Allah. ${ }^{23}$ Tawaran lainnya tentang pemaknaan maqâsid al-sharîah dengan pencarian nilai-nilai universal berasal dari Abdullah Saeed dengan teori kontekstual dan ethico-legalnya. Jasser Auda menambahkan bahwa maqâsid al-sharîah adalah wisdoms behind rulings (rahasia-rahasia di balik ketentuan hukum) dalam bingkai prinsip-prinsip moralitas (morality), universalitas (universality), keadilan sosial (social justice), kemanusiaan (buman dignity), hak asasi manusia (buman rights) dalam rangka untuk memberikan jawaban atas berbagai persoalan yang dihadapi baik oleh komunitas Muslim maupun non-Muslim. ${ }^{24}$

\section{Kaidah dan Cara Mengungkap Maqâșid al-Sharî‘ah}

Menurut Ibn Taymîyah (w. $728 \mathrm{H}$ ), sebagaimana ditulis oleh alBadâwî dalam disertasinya, ada enam cara untuk mengungkap maqâsid al-sharíah, yaitu: pertama, istiqrâ' (penalaran induktif). Kedua, memahami kaidah-kaidah bahasa Arab (dabt al-lisân al-'Arabîyah). ${ }^{25}$ Ketiga, merujuk kepada pendapat para sahabat (aqwâl al-șahâbah). Keempat, memahami konteks pembicaraan (siyâq al-kalâm). Kelima, membedakan antara tujuan pokok (al-maqâsid al-așîyah) dan tujuan yang bersifat akibat (al-

22 al-Khâdimî, Abḥâth fî̀ Maqậịid al-Sharîah, 14.

${ }^{23}$ Wahbah al-Zuhaylî, Ușûl al-Fiqh al-Islâmî, Vol. 2 (Damaskus: Dâr al-Fikr, 1986), 225.

${ }^{24}$ Auda, Maqâsid al-Sharîah, 1-2, 23-25.

25 Menurut Ibn Taymîyah, kaidah-kaidah bahasa Arab bukan tujuan, akan tetapi tidak lebih dari sebuah sarana untuk bisa memahami al-Qur'ân secara komprehensif dan akurat karena al-Qur'ân ditulis dalam bahasa Arab, meskipun al-Qur'ân juga mengandung banyak istilah, kaidah yang bukan berasal dari bahasa Arab. 
maqậsid al-tabi (ýab). Dan keenam, melaksanakan ketentuan naṣs menurut kadar kemampuan ketika tidak disebutkan tujuan secara jelas. $^{26}$

Beranjak dari Ibn Taymîyah, Imâm al-Shâțibî ${ }^{27}$ mencatat bahwa maqâsid al-sharî́ah bisa diungkap melalui empat cara. Pertama, memahami makna perintah (amr) dan larangan (naby). Kedua, mengungkap illah dari sebuah perintah dan larangan. Ketiga, mengungkap tujuan sharî‘ah yang bersifat pokok (al-askîyab) dan cabang/yang mengikuti (tabi $y$ yah). Dan keempat, pencarian nilai maslahah yang tersirat dari nass. Teori inilah yang nantinya akan dikembangkan oleh Ibn 'Âshûr terutama pada wilayah maslahat dan terus dikembangkan para maqâsidiyyûn kontemporer termasuk Jasser Auda. Berikut adalah kaidah dan sekaligus cara mengungkap maksud sharî́ah (al-turuq li kashf maqâsidi al-shâri'):

1. Mujarrad al-amr wa al-naby al-ibtidâî al-tasrị̣̂̂̂ (Perintah dan larangan yang telah jelas yang berada di awal ayat)

Cara pertama adalah memahami makna perintah (al-amr) dan larangan (al-naby) yang berada di awal ayat dan jelas. Metode ini tergolong metode yang menekankan pada pendekatan linguistik atau kebahasaan. Al-Shâtibîi menjelaskan bahwa makna sebuah perintah adalah menunjukkan kewajiban untuk dilaksanakan, sedangkan makna larangan menunjukkan kewajiban untuk ditinggalkan. Maka perbuatan melaksanakan perintah dan menjauhi larangan adalah bentuk dari maqâsid al-shâri' (kehendak pembuat sharî‘ah). ${ }^{28}$

a. Maksud dari 'perintah di awal ayat' adalah apa yang menjadi maksud dari pembuat sharî'ah, seperti dinyatakan dalam al-Qur'ân, surat al-Jum'ah [45]: 9 fa is'aw ilâ dhikr Allâh wa dharû al-bay' (maka

${ }^{26}$ Dalam disertasinya, al-Badâwî menjelasan secara panjang lebar tentang konsep maqâsid al-sharîah terutama metode untuk mengungkap maqâsid al-sharîah. Disertasi yang kemudian dicetak dalam bentuk buku ini sempat mendapatkan apresiasi dari para penguji dengan predikat cumlaude. Lihat Yûsuf Aḥmad Muḥammad al-Badâwî, Maqâsid al-Sharîah 'ind Ibn Taymîyah (Ardân: Dâr al-Nafâis li al-Nashr wa al-Tawzî', 1999), 201-240. Menanggapi poin yang terakhir ini, al-Shâțibî menegaskan bahwa jika seorang mujtahid mampu menemukan tujuan sharî‘ ah yang tidak ada ketentuan secara jelas dalam nass, jika temuan itu baik dan selaras dengan spirit nass, maka temuannya bisa diterima. Akan tetapi jika temuan itu justru bertolak belakang dengan nilai-nilai dasar sharî‘ ah, maka temuannya tidak bisa diterima atau batal. Lihat al-Shâtịîi, al-Muwâfaqât, Vol. 2, 685.

27 Ibid., 275.

28 Ibid., 667. 
bersegeralah untuk mengingat Allah dan tinggalkanlah jual beli). Maka 'perintah bersegera untuk mengingat Allah adalah maqâsid alshâri', sedangkan perintah untuk meninggalkan jual beli adalah maksud kedua, maksud yang mengikuti, maksud yang bersifat khafì, dan maksud yang tidak memiliki ketetapan hukum yang kuat (ghayr al-wâdịh fì al-dalâlab).

b. 'Perintah' dan 'larangan' yang telah jelas seperti dalam surat alJum'ah di atas juga menuntut adanya makna sebaliknya yakni 'meninggalkan' atau 'melakukan' seperti dalam kaidah al-amr bi alshay' nahy 'an diddih (perintah melakukan sesuatu berarti juga larangan untuk melakukan kebalikannya). ${ }^{29}$ Melakukan perintah dan larangan adalah maksud sang pembuat sharî‘ah, sedangkan menjalankan kebalikannya adalah maksud yang kedua.

2. I'tibâr 'ilal al-amr wa al-nahy (Mengungkap 'illah dari sebuah perintah atau larangan)

Cara kedua, lanjut al-Shâtibî, adalah dengan mengungkap 'illab dari sebuah 'perintah' atau 'larangan', seperti perintah menikah adalah karena maslahah bagi keturunan, perintah jual-beli adalah supaya bisa saling mengambil manfaat dari kedua belah pihak, dan hukum qisâs supaya tidak terjadi kejahatan ${ }^{30}$ dan seterusnya, seperti kaidah "almaqâșid al-sharîyah tadûr ma'a 'illat al-hukm wujûdan wa 'adaman" (tujuan shari'ah tergantung pada ada atau tidaknya 'illah hukum). ${ }^{31}$ Akan tetapi jika illah hukum tidak mampu ditemukan, maka harus dicari 'illah baru yang mencerminkan maslahah. ${ }^{32}$

3. Al-Maqâsid al-aslîyah wa al-maqâsid al-tabi'ŷah (Tujuan sharî́ah yang bersifat pokok dan cabang)

Selanjutnya, cara ketiga adalah mengungkap tujuan sharî‘ah yang bersifat pokok (al-asilyab) dan cabang (tabi ýab) seperti dalam kaidah "fa inna li al-shâri' fî shar' al-aḥkâm al-'âdîyah wa al-'ibâdîyah maqâșid aṣlîyah tâbi'ah" (Sesungguhnya, ketika sang pembuat sharî́ah

${ }^{29}$ Lihạâasanah, al-Fiqh al-Maqậid, 99. Lihat juga al-Shâtibî, al-Muwâfaqât, Vol. 2, 668. Menurut Wahbah al-Zuhaylî, kaidah ini telah disepakati oleh mayoritas ulama usûl kecuali Mu'tazilah. Sebagai contoh larangan 'berdiri' berarti menunjukkan perintah 'duduk' dan seterusnya. Lihat al-Zuhaylî, Usûul al-Fiqh, 228.

30 al-Shâtibî, al-Munâfaqât, Vol. 2, 668.

${ }^{31}$ Kaidah ini hampir ada di setiap pembahasan tentang usûl al-fiqh. Lihat Muhammad al-Amîn b. Muhammad al-Mukhtâr al-Juknî al-Shanqîtî̀, Mudhakekarah Ușû́l al-Fiqh 'alâ Radat al-Naz̧ir (Madinah: Maktabat al-'Ulûm wa al-Hịikam, t.th.), 33-34.

32 al-Shâtibî, al-Munvâfaqât, Vol. 2, 669. 
menetapkan hukum-hukum baik berupa kebiasaan atau ibadah pasti mengandung tujuan yang bersifat pokok dan tujuan yang bersifat cabang). ${ }^{33}$ Tujuan pokok berfungsi sebagai ketentuan hukum, sedangkan tujuan yang mengikuti lebih berfungsi sebagai penguat, pelengkap, dan penyempurna dari tujuan pokok. Sebagai contoh ketika al-Shâtibî memahami maksud ayat inna al-salâh tanhâ 'an alfahshâ' wa al-munkar (sesungguhnya salat bisa mencegah dari perbuatan keji dan mungkar). Al-Shâțibî, sebagaimana Ibn Taymîyah, menjadikan 'ingat kepada Allah' adalah maqậsid al-așlŷah dari ibadah salat. Sedangkan 'mencegah dari perbuatan keji dan munkar' adalah maqâsid al-tâbi ah. Contoh lain dari tujuan pokok (al-maqâșid al-așlîyah) adalah melangsungkan keturunan, kemudian diikuti tujuan kedua (almaqâsid al-tabi'ŷah) berupa 'mencari ketenangan', 'mencari kenikmatan dengan cara yang halal', 'menjaga agar tidak terjerumus'. Jika tujuan pokok memiliki rujukan dalam nass, maka tujuan yang mengikuti lebih didasarkan pada pelacakan hikmah di balik tujuan pokok. ${ }^{34}$

4. Sukût al-shâri' (Tidak adanya petunjuk jelas dari pembuat hukum)

Cara keempat adalah pencarian maslahah. Ini disebabkan karena tidak adanya petunjuk secara jelas dalam bentuk perintah atau larangan, diwajibkan atau dilarang, boleh dilakukan atau tidak yang tertuang dalam naș dan terjadi pasca-kenabian (companion). Dalam kondisi semacam ini, al-Shâtibîi mengambil jalan pencarian mașlahat almursalah sebagaimana yang dilakukan para fuqahâ' salaf dengan menjadikan kebutuhan darûrîyat sebagai barometer kekuatan maslahah itu. Ia kemudian menyusun kaidah fa ị̣tâj abl al-sharîab ilâ al-naz̧r fî̀ â wa ijrâihâ 'alâ mâ taqarrar fî kulliyyâtihâ wa tubnâ akthar aḅkâm hâdhâ alnaw' 'alâ al-masâlị̣ al-mursalah (maka, dalam keadaan semacam ini, para ahli hukum Islam harus melakukan penelitian tentang persoalan itu dan mengoperasionalkan berdasarkan ketentuan yang ada pada kebutuhan darûriyyât kemudian barulah dibangun ketentuan hukum

33 Ibid., 670.

34 Ibid., 671. Konsep al-Shâtibî tentang klasifikasi maqâsid aslîyah dan maqậid altabi'ŷah, menurut Abû 'Ubaydah, sering merujuk pada pemikiran Ibn Taymîyah. Lihat Abû Ishâa al-Shâtibîi, al-I'tisâm, Vol. 1, ed. Abû 'Ubaydah (t.t.: Maktabat alTawhîd, t.th.), 86-87. Lihat juga penjelasan dalam tesis al-Najrân yang sudah dicetak menjadi buku tentang pembahasan ini. Lihat Sulaymân b. Muḥammad b. 'Abd Allâh al-Najrân, al-Mufâdalah fì al-Tbâdât: Qawầid wa Tatbîqât (Riyad: t.p., 2004), 271-272; 'Abd Allâh b. 'Abd Raḥmân al-Bassâmî, Tawdîh al-Aḥkâm min Bulùgh al-Marâm, Vol. 1 (Makkah al-Mukarramah: Maktabat al-Asâdî, 2003), 91. 
baru berdasarkan maslahat al-mursalah). ${ }^{35}$ Contoh cara keempat ini adalah pengumpulan musḥaf, kodifikasi hadîth, dan beberapa kasus baru lainnya.

Ibn 'Âshûr menjelaskan sekaligus mengembangkan teori al-Shâtibî dengan menawarkan tiga format yang sama sekali baru dalam menentukan maqâsid al-sharî'ah. Pertama adalah pencarian illah melalui pola pikir induksi (istiqrâ). Kedua, melalui dalil-dalil al-Qur'ân yang secara tegas menyebutkan tujuan sharî́ah (adillat al-Qur'ân al-wâdihah al-șarîhah fî̀ dalâlatih â). Dan ketiga, melalui dalil-dalil sunnah yang mutâwatir, baik secara ma'nawî atau 'amalî (al-sunnah al-mutawâtirah: altawâtur al-ma'nawî aw al-tawâtur al-'amalì). ${ }^{37}$

\section{Istiqrâ' (induksi)}

Istiqrâ' secara etimologis berarti pengikutsertaan atau terusmenerus (al-tatâbu'). Dalam istilah yang lebih populer, istiqrâ' disebut juga dengan induksi (lawan dari deduksi), yaitu sebuah metode berpikir yang bertolak dari suatu yang khusus menuju yang umum, kadang-kadang juga bertolak dari yang kurang umum menuju yang lebih umum. ${ }^{38}$ Dalam istilah ilmu hukum Islam, istiqrấ' (induksi) adalah sebuah metode pengambilan kesimpulan umum yang dihasilkan oleh fakta-fakta khusus. ${ }^{39}$ Metode ini sering digunakan oleh para fuqahâ' terutama dalam menetapkan suatu hukum. ${ }^{40}$ Imam alShâfi' $\hat{i}$ tergolong salah satu dari para fuqahâ' yang acap kali

35 al-Shâtibî, al-Muwâfaqât, Vol. 2, 671.

36 Ibid., 672.

${ }^{37}$ Ibn 'Âshûr, Maqâsid al-Sharîah, 189-196.

38 Muḥammad Hasan Hasan Jabal, Difâ' 'an al-Qur'ân al-Karîm: Usâlat al-A'râb wa Dalâlatuh 'alâ al-Ma'ânî fî al-Qur'ân al-Karîm wa al-Lughab al-'Arabîyah (Beirut: alTabâ'ah al-Ḥadîthah, 2000), 114.

39 Aḥmad b. 'Abd al-Hạaîm, Majmû' al-Fatâwâ li Shaykh al-Islâm Taqîy al-Dîn Ibn Taymîyah al-Ḥarrânî, Vol. 9 (t.t.: Dâr al-Wafâ’ li al-Tịbâ'ah wa al-Nashr wa al-Tawzî́, 2005), 106.

${ }^{40}$ Sebagai contoh penerapan metode istiqrâ' dalam usûl al-figh adalah prinsip bahwa al-amr fì al-amr li al-wujūb (pada prinsipnya kalimat perintah menunjukkan hukum wajib). Kesimpulan ini diambil berdasarkan pada satuan-satuan pernyataan (premis) berupa: (1) dalil nass yang menunjukkan celaan bagi orang yang tidak mengindahkan perintah Allâh; (2) dalil naș yang menunjukkan ancaman bagi orang yang tidak melaksanakan perintah; (3) pernyataan Nabi berupa perintah atau tindakan memberi contoh yang kemudian dipahami para sahabatnya sebagai sesuatu yang wajib dilaksanakan dan anggapan mereka dibenarkan oleh Nabi sendiri; dan (4) aspek kebahasaan menunjukkan bahwa fíl 'amr (kalimat perintah) menunjukkan wajib kecuali ada indikasi yang menunjukkan makna lain. 
mengoperasionalkan metode istiqrâ' terutama dalam menentukan waktu lamanya menstruasi bagi wanita. ${ }^{41}$ Kelompok rasionalis menterjemahkan istiqrâ' dengan al-hukem 'alâ al-jur'iyyât li ithbât al-ḅukm al-kullit (menarik kesimpulan umum berdasarkan karakterisik satuansatuannya).

Pada dasarnya, metode istiqrâ' adalah metode berpikir induktifempiris dalam penetapan hukum Islam. Hal ini tentu saja berhubungan erat dengan sumber-sumber hukum dalam Islam yakni al-Qur'ân dan hadîth. Sebagaimana diketahui bahwa cukup banyak teks al-Qur'ân dan hadîth yang hanya memaparkan norma-norma dan nilai-nilai dasar yang bersifat universal, sehingga untuk memahami teks-teks semacam itu diperlukan metode pemikiran tertentu agar sebuah teks dapat dipahami kandungannya dan dapat diperoleh sebuah ketetapan hukum darinya. Di samping itu, metode istiqrâ' juga merupakan bagian dari tata kerja epistemologi, yaitu dengan menjadikan teks al-Qur'ân dan hạaith sebagai kerangka referensialotoritatif sebagai landasan membangun pengetahuan. Setidaknya ada dua cara untuk mendapatkan pengetahuan dari teks, yaitu berpegang pada makna literal teks dan berpegang pada maksud atau sasaran teks yang sebenarnya. ${ }^{43}$

Seperti yang dikatakan al-Shâtibî dan Ibn 'Âshûr bahwa istiqrâ' adalah salah satu metode yang tepat untuk mengidentifikasi maqâsid al-

41 al-Shâfíî menetapkan hukum masa haid terpendek adalah sehari semalam, masa yang lumrah enam atau tujuh hari atau tujuh malam, dan masa haid yang terpanjang adalah lima belas hari atau lima belas malam. Penetapan hukum semacam ini dilakukan oleh al-Shâfîî berdasarkan penelitian atas beberapa wanita di Mesir yang kemudian ia tetapkan sebagai ketentuan hukum fiqh bagi semua wanita di dunia.

42 al-Tahânawî, Mawsu'at Kashshâf, 172.

43 Contoh dalam hukum fiqh "salat lima waktu hukumnya wajib". Kesimpulan ini tidak hanya didasarkan pada satu penggalan ayat saja, tetapi harus dilakukan penelitian (istiqrâ) untuk mencari ayat-ayat lain yang akan mendukung hasil kesimpulan nanti. Hukum wajib salat dihasilkan oleh penelitian istiqrầi bahwa; (1) banyak ayat yang mengandung 'amr untuk melaksanakan salat; (2) penghargaan khusus kepada orang yang melaksanakan salat; (3) ancaman bagi yang meninggalkan salat; (4) perintah melaksanakan salat dalam kondisi apapun, baik dalam keadaan sehat atau sakit, situasi aman atau dalam peperangan, duduk atau berdiri dan sebagainya; dan (5) riwayat secara mutawâtir dari Nabi hingga saat ini yang menunjukkan bahwa umat Islam memelihara pelaksanaan salat. Pernyataan satu sampai lima tersebut sudah diuji kebenarannya. Ternyata kebanyakan premis tersebut menunjukkan bahwa salat itu hukumnya wajib. Karena menyangkut persoalan agama, maka kesimpulan yang diperoleh dari istiqrâ' nâqiṣ dengan mutu zann harus meyakinkan. 
sharíah. Metode ini tertuang dalam usûl al-fiqh yang juga dibutuhkan para mujtahid untuk menjelaskan sekaligus menjawab persoalanpersoalan hukum dengan mudah. ${ }^{44}$ Hal ini disebabkan karena meskipun naṣs (al-Qur'ân dan hadîth) memiliki tingkat kebenaran absolut, akan tetapi pemahaman terhadap nasss lebih bersifat relatif. Dari kesadaran inilah para mujtahid berupaya bagaimana hukum Islam tetap mampu mengawal berbagai capaian kemajuan di banyak aspek kehidupan. Dalam metode istigrâ', yang menjadi objek kajian adalah teks dan konteks (al-nașs wa al-wâqi). Teks adalah mencermati zahir nașs, sedangkan konteks adalah makna substansi yang terkandung dalam sebuah teks. Makna substansi tidak boleh merusak arti zahir suatu nass, dan sebaliknya.

Ada dua macam istiqrâ', yaitu istiqrâ' tâmm ${ }^{45}$ (induksi sempurna) dan istiqrâ' nâqis ${ }^{46}$ (induksi tidak sempurna). Jika kesimpulan itu didasarkan atas kesamaan karakteristik semua satuannya disebut istiqrâ' tâmm dan memiliki kekuatan hukum yang bersifat qat ${ }^{\prime \prime \imath}{ }^{47}$ Akan tetapi jika kesimpulan didasarkan atas kesamaan sebagian karakter satuannya disebut istiqrâ' nâqis ${ }^{48}$ dan memiliki kekuatan hukum yang bersifat zann. Dalam tradisi keilmuan usûl al-fiqh, metode induksi digunakan, antara lain, dalam menetapkan suatu kaedah umum untuk membahas persoalan-persoalan hukum atau menetapkan hukum fiqh 'amalî (praktis); apakah persoalan itu wajib, sunnah, mubâh, makrûh, haram, halal, sah, batal atau fâsid.

Para ulama usûl silang pendapat tentang kekuatan hukum kedua jenis istiqrâ' ini. Akan tetapi al-Ghazâlî, ${ }^{49}$ Ibn Najjâr, dan kebanyakan ulama ușûl sepakat bahwa istiqrâ' tâmm memiliki kekuatan hukum qat 'î̀,

\footnotetext{
44 al-Shâțibî, al-Munvâfaqât, Vol. 2, 323.

45 Istiqrầ Tâmm biasanya ditemukan dalam penelitian tentang ilmu-ilmu alam di mana karakteristik objek-objek yang diteliti bersifat konstan,

46 al-Badâwî, Maqâsid al-Sharî'ah, 203. Dalam wilayah kajian hukum Islam, istiqrâ' nâqis menempatkan al-Qur'ân, hadîth, dan pendapat para ulama yang memiliki otoritas sebagai objek utama. Eksistensi istiqrâ' nâqis dalam ranah ilmu-ilmu sosial disebabkan karakteristik perilaku manusia dan pranata sosial tidak konstan, begitu pula otoritas hukum (dalâlah) ayat al-Qur'ân dan hadîth yang mendukung jarang disepakati kepastian maknanya. Karena itu, hanya dapat dilakukan dengan istiqrâ' nâqis yang menghasilkan kesimpulan zann (kemungkinan besar benar).

47 Hussâm Muhy al-Dîn al-Âlûsî, Madkhal ilâ al-Falsafah (Beirut: al-Muassasat al'Arabîyah li al-Dirâsât wa al-Nashr al-Markâz al-Raisî, 2005), 86.

48 al-Badâwî, Maqâsid al-Sharîah, 203.

49 al-Ḥalìm, Majmû' al-Fatâwâ, Vol. 9, 106-107.
} 
sedangkan istiqrâ' nâqis bersifat zann. Berbeda dari pendapat di atas, alShâfi $\hat{i}$ dan Ibn Taymîyah berpendapat bahwa keduanya (tâmm atau nâqis) memiliki kekuatan hukum qat tî̀ selagi tidak kontradiksi dengan substansi ajaran Islam. ${ }^{50}$

a. Istiqrâ' al-ahkêm al-ma'rûfah 'illatubâ bi maslak al-illah (Penelitian terhadap hukum-hukum yang telah diketahui illah-nya)

Mengkaji dan meneliti semua hukum yang diketahui illah-nya. Dengan meneliti 'illah, maka maqâsid akan dapat diketahui dengan mudah. Contoh, larangan melamar perempuan yang sudah dilamar orang lain, dan larangan menawar sesuatu yang sudah ditawar orang lain sebagai premis mayor. Tllah dari larangan itu adalah 'keserakahan' dengan menghalangi kepentingan orang lain sebagai premis minor. Dari sana dapat diambil satu tujuan/maqsad, yaitu langgengnya persaudaraan antara saudara seiman. Berdasarkan maqsad tersebut, maka tidak haram meminang pinangan orang lain setelah pelamar pertama mencabut keinginannya itu. ${ }^{51}$

b. Istiqrâ' adillat al-aḅkâm ishtarakat fì 'illah wâhidah (Penelitian terhadap dalil-dalil hukum yang memiliki kandungan 'illah yang sama)

Meneliti dalil-dalil hukum yang memiliki kandungan 'illah yang sama sampai dirasa yakin bahwa illah tersebut adalah maqsad-nya, seperti banyaknya perintah untuk memerdekakan budak menunjukkan bahwa salah satu maqậid al-sharîah adalah adanya kebebasan (al-hurrîyah).

2. Adillat al-Qur'ân al-wậdihah al-sarî̉ah fî dalâlâtihâ (Penelitian terhadap dalil-dalil al-Qur'ân yang secara jelas dan tegas memuat kandungan hukum)

Cara kedua dalam melacak maqậid al-sharîab adalah melalui penelitian terhadap dalil-dalil al-Qur'ân yang secara jelas dan tegas memuat tentang kandungan hukum, sehingga kemungkinan kecil mengartikan bukan pada makna zahirnya. Seperti dalam Q.S. alBaqarah [2]: 205 wa Allâh lâ yubibb al-fasâd (dan Allah tidak menyukai kerusakan), Q.S. al-Baqarah [2]: 185 ... yurîd Allâh bikum al-yusr wa lâ yurîd bikum al-usr (... Allah menghendaki kemudahan bagimu dan tidak menghendaki kesukaran bagimu), dan Q.S. al-Hajaj [22]: 78 ... wa mâ jáala 'alaykum fì al-dîn min haraj (... dan Allah sekali-kali tidak menjadikan kesempitan dalam agama). Menurut Ibn 'Âshûr, maqâsid

50 al-Badâwî, Maqâsìid al-Sharíah, 203.

${ }^{51}$ Lihạasâsanah, al-Fiqh al-Maqậid, 104-105. 
dari ayat-ayat di atas bisa ditemukan dari zahir nass. Dengan demikian, naș berkedudukan sebagai premis mayor dan 'zahir' sebagai premis minor, dan makna 'kerusakan', 'kemudahan', dan 'kesulitan' berfungsi sebagai konklusi atau maksud sharî́ah.

\section{Al-Sunnah al-Mutawâtirah}

Cara ketiga untuk mengungkap maksud sharî́ah adalah melakukan observasi terhadap dalil-dalil sunnah yang mutawatir, baik secara maknawi atau amali (al-tawâtur al-ma'nawî dan al-tawâtur al-'amalì). Mutawatir ma'nawî adalah kesaksian sahabat bahwa Nabi pernah melakukan sesuatu, maka status apa yang dilakukan Nabi saat itu adalah maqâsidal-darûriyyât. Contoh dari mutawâtir maknawi adalah sedekah jâriyah dan mendahulukan salat dari khutbah dalam salat hari raya.

Sedangkan contoh mutawatir 'amalî adalah hadîth sahih riwayat alBukhârî dan Muslim tentang seorang sahabat bernama Abû Barzah yang membatalkan salatnya karena mencari kudanya yang lepas. Setelah ia mendapatkan kudanya, ia segera mengulang salatnya. Ketika dikonfirmasi kepada Nabi, Nabi mengatakan bahwa membatalkan salat demi keselamatan (kendaraan) kuda adalah lebih baik daripada dia kehilangan kudanya dan harus pulang ke rumah dengan jalan kaki. Maqâsid al-sharîab dari kasus ini adalah kemudahan (al-taysîr). ${ }^{52}$

\section{Kontroversi Penutupan Ijtihad}

Pada awal abad ke-10 Masehi, mazhab hukum Sunnî telah mencapai tingkat kematangan di mana semua persoalan besar mengenai masalah-masalah hukum positif bisa diselesaikan. Sistem peradilan yang telah mapan saat ini adalah bukti kematangan intelektualitas para sarjana Muslim yang juga ditopang dengan metodologi hukum yang memadai. Akan tetapi, prestasi besar para ulama klasik itu tiba-tiba dikejutkan oleh adanya pernyataan kontroversi tentang isu the closing of the gate of ijtihad (pintu ijtihad tertutup $^{53}$ yang berdampak pada kebekuan perkembangan hukum Islam terhitung sejak awal abad sepuluh Masehi. ${ }^{54}$

\footnotetext{
52 Hadîth tentang hal ini dimuat dalam Șahîh al-Bukhârî pada bab 'amal fì al-salâh, hadith no. 1211, Vol. 2, 367.

53 Shaykh Abû Zahrah secara tegas menolak isu itu dengan mengatakan bahwa dalam tradisi Shî‘ah Imâmîyah (khususnya) tidak pernah ada pernyataan "pintu ijtihad tertutup". Ia selalu terbuka, dan bahkan para imam Shî‘ah Imâmah tidak pernah melarang hal itu. Lihat Hạnnân Muhammad 'Abd al-Majîd Ibrâhîm, alTaghayyur al-Ijtimầî̀ fì al-Fiker al-Islâmî al-Hẹadîth: Dirâsat Tạ̣lîlìyah Naqdîyah (Herndon,
} 
Untuk memahami kontradiksi seputar isu pintu ijtihad tertutup, maka perlu dipahami terlebih dahulu makna ijtihad, karena para sarjana yang menggunakan istilah ijtihad memiliki persepsi yang berbeda tentang konsep ijtihad. Arti ijtihad telah berubah dari waktu ke waktu dan telah dirasakan dalam berbagai konteks oleh berbagai ulama sepanjang sejarah hukum Islam. Beberapa definisi ijtihad yang diberikan para sarjana Muslim secara kronologis adalah sebagai berikut: (1) al-Shâfîî (w. $204 \mathrm{H} / 819$ M): "ijtihad terdiri dari analogi (qiyâs)", 55 (2) Ibn Hazm (w. $456 \mathrm{H} / 1064$ M): "ijtihad berarti melakukan investigasi ketentuan Tuhan melalui al-Qur'ân dan Sunnah", 56 (3) Abû Ishâk Shîrazî (w. 476 H/1083 M): "ijtihad adalah lebih umum daripada analogi karena ijtihad berarti berusaha keras untuk mencapai ketentuan hukum tertentu", ${ }^{57}$ (4) al-Ghazâlî (w. 505 H/1111 M): "ijtihad berarti upaya maksimal oleh seorang mujtahid dalam mempelajari ketentuan-ketentuan agama", ${ }^{8}$ dan (5) Muṣtafâ alShalabî: "ijtihad berarti upaya untuk mengekstrak hukum-hukum agama, simbol-simbol, ekspresi, dan makna teks yang amat dalam". ${ }^{9}$

Realitas, esensi, dan cakupan ijtihad sendiri masih menjadi sumber perdebatan dari abad kedua Hijriyah sampai hari ini. Beberapa sejarawan Muslim dan sarjana Barat menegaskan bahwa hak untuk menggunakan kemampuan berijtihad secara individu telah dibekukan dalam tradisi Sunni sekitar awal abad ke 10 Masehi. ${ }^{60}$ Istilah yang sangat populer adalah the closing of the gate of ijtihad. Menurut Wael B.

London: al-Ma'had al-'Âlamî li al-Fikr al-Islâmî, 2011), 141. Isu the closure of the gate of ijtihâd ini bisa ditemukan misalnya dalam beberapa literatur yang ditulis oleh 'Ubayd Allâh b. Husayn al-Karhî (w. 340 H/951 M) ulama mazhab Ḥanafî, Bakr b. al-A'lâ (w. $344 \mathrm{H} / 955 \mathrm{M}$ ) dari mazhab Mâlikî. Tidak ditemukan pada periode sebelum keduanya. Lihat Kesgin, "A Critical Analysis”, 163.

${ }^{54}$ Ibid., 158.

55 Muḥammad b. Idrîs al-Shâfiî̀, al-Risâlah fî Usûul al-Fiqh, ed. Ahmad Muhammed Shakir (Kairo: Maṭba'at al-Musțafâ al-Bâb al-Ḥalabî, 1940), 477.

${ }^{56}$ Ibn Hazm, al-Iḥkâm fî Ușûl al-Aḅkâm (Mesir: al-Aṣma, t.th.), 41.

57 Abû Ishâq Shîrâzî, Kitâb al-Luma' fî̀ Ușull al-Fiqh (Kairo: Dâr al-Nadwah alIslâmîyah, 1988), 123.

58 Abû Hâmid al-Ghazâlî, al-Mustaşâ min Tlm al-Ușull, Vol. 2 (Kairo: Maṭba'at Muștafâ Muhammed, 1973), 101.

${ }^{59}$ Muhammad Muștafâ Shalabî, Ta lîl al-Aḥkâm (Mesir: t.p., 1974), 11.

${ }^{60}$ Joseph Schacht, An Introduction to Islamic Law (Oxford: Oxford University Press, 1979), 71-72.

330 ISLAMICA, VOLUME 8, NOMOR 2, MARET 2014 
Hallaq, kesaksian sejarah itu tidaklah benar. ${ }^{61}$ Beberapa sarjana Barat lainnya seperti W. Montgomery Watt dan Bernard Weiss lebih memilih posisi tengah. Selain itu, ada beberapa pernyataan bahwa gagasan penutupan pintu ijtihad tidak memroyeksikan realitas sebenarnya. Karena praktik ijtihad bukan hanya hak mutlak empat mazhab hukum yang ada, tetapi hak bagi setiap Muslim yang telah memiliki kapabilitas yang memadai.

Para fuqahâ' sepakat bahwa prinsip ijtihad bermuara pada hadîth tentang peristiwa antara Nabi dan Mu'âdh b. Jabal pada saat dilantik menjadi hakim ( $q \hat{a} d \hat{\imath} \hat{)}$ di Yaman. Kondisi ini terus berlangsung sampai masa al-Khulafấ al-Râshidûn dan periode Umayyah yang dikenal dengan istilah al-ijtibâd bi al-ra'y ${ }^{62}$ sampai dengan abad ke-8 M. Pasca-abad ke-8 M ijtihad secara bertahap dipisahkan dari ra'y. Muhammad b. Idrîs alShâfiî̀ (w. 204 H/819 M), pendiri mazhab fiqh Shâfî̀, adalah yang pertama menentang ra'y dan lebih memilih metode ijtihad melalui qiyâs atau analogi deduktif. Gagasan besar al-Shâfîî secara gamblang dijelaskan dalam kitab yang cukup terkenal al-Risâlah fî Usûl al-Fiqh. Ide itu kemudian terus dikembangkan oleh para ulama berikutnya dengan mengenalkan konsep istihsân dan istiş̧âh. Pada abad kedua puluh, diskusi tentang isu the closing of the gate of ijtihad mulai menghangat kembali baik di kalangan para sarjana Barat atau sarjana Muslim. Setidaknya ada tiga gelombang besar yang merespons isu di atas.

Pertama, para sarjana yang percaya bahwa pintu ijtihad ditutup adalah dari kalangan orientalis. Joseph Schacht mengklaim bahwa pada awal abad ke-10 Masehi, hukum Islam telah mengalami kematangan sehingga para ulama mengambil kesimpulan bahwa semua permasalahan bisa dicarikan solusi dari pendapat para imam mazhab. Schacht menambahkan:

... around 900 C.E., a consensus gradually established itself to the effect that from that time onwards no one might be deemed to have the

\footnotetext{
${ }^{61}$ Wael B. Hallaq, "Was the Gate of Ijtihâd Closed?”, International Journal of Middle East Studies, 16 (1984), 3-41.

62 Ada juga beberapa sumber yang mengatakan bahwa orang pertama yang memperkenalkan istilah qiyâs adalah Imâm Abû Ḥanifah ketika ia menemukan sebuah kasus yang tidak ada dasarnya dalam nașs, hạaith, dan fatwa sahabat. Lihat Akgündüz Ahmet, Introduction to Islamic Law: Islamic Law in Theory and Practice (Rotterdam: IUR Press, 2010), 152; 'Abd al-Husayn Sharaf al-Dîn Musâwî, al-Nașs wa al-Ijtihâd (Tehran: Qism al-Dirâsah al-Islâmîyah, 1985), 66, 347; Schacht, $A n$ Introduction, 37.
} 
necessary qualifications for independent reasoning in law, and that all future activity would have to be confined to the explanation, application, and, at the most, interpretation of the doctrine as it had been laid down and for all. ${ }^{63}$

... sekitar tahun 900 Masehi, konsensus secara bertahap telah terbentuk dengan sendirinya sebagai akibat dari pernyataan bahwa tidak ada satupun orang yang memiliki kualifikasi untuk menjadi mujtahid mutlak, dan bahwa semua aktivitas di masa yang akan datang hanya terbatas pada penjelasan, mengaplikasikan, dan sebagian besar hanya sekadar penafsiran terhadap doktrin yang telah ditetapkan secara menyeluruh.

Kedua, para ahli yang percaya bahwa pintu ijtihad tidak pernah ditutup. Para sarjana yang berada di barisan ini adalah Wael B. Hallaq, Jamâl al-Dîn al-Afghânî (w. 1897 M), Muḥammad 'Abduh (w. 1905 M), Muḥammad Iqbâl (w. 1938 M), dan para ulama gerakan Salafi. Hallaq secara tegas menolak isu tersebut baik secara teoritis maupun secara praktis. Hallaq mengatakan: there was no consensus on the closure of the gate of ijtihâd as reported by Schacht, and that the ijtibâd was to be a continual effort in theory and no such invalidation of ijtibad happen historically (tidak ada konsensus mengenai penutupan pintu ijtihad sebagaimana yang dinyatakan oleh Schacht, dan bahwa ijtihad telah menjadi upaya terus-menerus dalam teori dan tidak ada upaya pembatalan ijtihad dalam sejarah). ${ }^{64}$

Ketiga, sarjana yang mengambil posisi tengah. Barisan tengah ini adalah Bernard Weiss, Edward Sell, Muhammad Ali, Muhammed Shâfîî, dan Ziya Gokalp. Mereka lebih memilih jalan tengah yakni "benar bahwa pintu ijtihad telah tertutup akan tetapi telah dibuka

${ }^{63}$ Schacht, An Introduction, 71-72. Coulson juga memilih sikap yang sama dengan Shacht. Ia mengatakan: "isu pintu ijtihad tertutup adalah mungkin lebih sebagai akibat dari tekanan internal umat Islam daripada faktor eksternal. Inti dari ijtihad telah dicapai ketika para ahli hukum Islam di awal abad ke-10 secara resmi dan mengakui bahwa kekuatan kreativitas mereka telah sepenuhnya dituangkan". Lihat N.J. Coulson, A History of Islamic Law (Edinburgh: Edinburgh University Press, 1964), 81. Tampaknya Fazlur Rahman juga sependapat dengan para orientalis. Ia mengatakan: “ $\ldots$ at the end of the third/ninth and beginning of the fourth/tenth centuries, both the dogma and the law had taken a definite shape, the ijma' arrived at by that time was declared final and the door of 'ijtihad' was closed". Lihat Fazlur Rahman, "Post-Formative Developments in IsIam" dalam Islamic Studies (Karachi: Gateway Publications, 1966), 87.

${ }^{64}$ Hallaq, "Was the Gate of Ijtihâd Closed?", 3-41. 
kembali seiring dengan kebutuhan dan berbagai persoalan baru yang mendesak untuk melakukan ijtihad" ${ }^{65}$

\section{Maqâșid sebagai Panduan Dasar Berijtihad}

Kata ijtihad diderivasi dari kata al-jubd atau al-jahd yang bermakna berjuang, bersungguh-sungguh, dan mengerahkan. Sedangkan dalam konteks fiqh, ijtihad didefinisikan dengan mengerahkan segala kemampuan untuk mengurai kasus-kasus hukum yang tidak disebutkan secara eksplisit dalam naṣs atau dalam ijmâ.6 ${ }^{66}$ Kata ini juga biasanya diidentikkan dengan retbinking ${ }^{67}$ atau independent reasoning. ${ }^{68}$ Sayf al-Dîn al-Âmidî (w. 731 H/1334 M) menefinisikan ijtihad dengan "upaya maksimal seorang yang memiliki kemampuan untuk memecahkan berbagai masalah hukum secara indvidu". "Edward Sell mendefinisikan ijtihad dengan "mencapai tingkat otoritas dalam menentukan prinsip-prinsip hukum".70 Secara teknis, istilah ijtihad menggambarkan tentang kemampuan seorang faqî̉ dalam mencari solusi atas kasus-kasus hukum yang merepresentasikan maslahah bagi komunitas Muslim. Para tokoh maqậsîdiyyun seperti Ibn 'Âshûr, Tâahâ Jâbir al-'Alwânî, Aḥmad al-Raysûnî, Jamâl al-Dîn 'Aț̣̂yah, dan lainlain juga sepakat bahwa hukum sharî́ah (al-Qur'ân) di samping memuat nilai-nilai juz'ŷyyat (parsial), ia juga mengandung nilai-nilai kulliyah (universal) yang seharusnya dipahami melalui pendekatan yang holistik (kullîyah) dalam aras kerangka berpikir maqâsid. ${ }^{71}$

Al-Shâtibî memberi aksentuasi bahwa pengetahuan maqâsid adalah prasyarat bagi seorang mujtahid saat ini. Penolakan terhadap maqâsid bisa berakibat fatal pada hasil ijtihad dan fatwa. Mereka yang menganggap teori maqâsisid sebagai ahli bid'ah adalah mereka yang memahami nass. secara tekstual dan kurang memberikan ruang pada aspek pemaknaan dan objek yang dimaksud. ${ }^{72}$ Menurut al-Shâtibî,

${ }^{65}$ Shaista P. Ali Karamali, "The Ijtihad Controversy", Arab Law Quarterly, Vol. 9, No. 3 (1994), 251-254.

${ }^{66}$ Nûr al-Dîn Mukhtâr al-Khâdimî, Abḥâth fì Maqâsid al-Sharî‘ah (Beirut: Muassasat al-Ma'ârif li al-Ṭabâ'ah wa al-Nashr, 2008), 170.

${ }^{67}$ Rahman, "Post-Formative", 12.

${ }^{68}$ Schacht, An Introduction, 69.

${ }^{69}$ Sayf al-Dîn al-Âmidî, al-Iḥkâm fì Usûl al-Aḥkâm, Vol. 4 (Beirut: Dâr al-Kitâb al'Arabî, 1984), 169.

${ }^{70}$ Edward Sell, The Faith in Islamic Law (London: t.p., 1896), 32.

${ }^{71}$ Muhammad Hashîm Kamâlî, Principles of Islamic Jurisprudence (t.t.: Islamic Texts Society, 2003), 179.

${ }^{72}$ Liḥasâsanah, al-Fiqh al-Maqậid, 26-27. 
signifikansi maqậsid sebagai kerangka berpikir epistemik dalam ijtihad adalah:

a. Untuk memahami suatu ungkapan nașs baik al-Qur'ân maupun hadîth kemudian mengekstrak maksud nașs tersebut melalui pendekatan kaidah linguistik (linguistic maxim) yang biasa dioperasionalkan dalam disiplin usûl al-fiqh.

b. Untuk mencari titik temu dalam kasus adanya dalil yang kontradiksi (ta âruḍ) menurut para fuqabâ'.

c. Untuk menegaskan tentang pentingnya analogi, illah, dan hikmah yang terkandung dalam nass.

d. Untuk memberi panduan dalam mengimplementasikan suatu perbuatan yang tidak ada ketentuan dalam naṣs melalui pertimbangan maslahat.

e. Dalam kasus tertentu di mana seorang mujtahid tidak mampu melacak tujuan pembuat sharî́ah, maka mengaplikasikan ketentuan nass secara tekstual adalah lebih baik sebagai bentuk penghambaan (al-ta'abbudì). ${ }^{73}$

f. Harus ada kesadaran untuk melakukan penelitian yang mendalam tentang kasus-kasus yang tidak disebutkan secara langsung dalam teks dengan cara istiqrâ. ${ }^{74}$

Senada dengan al-Shâtibî, Ibn 'Âshûr menegaskan bahwa pengetahuan tentang maqâsid sangat diperlukan untuk ijtihad dan segala bentuk manifestasinya. Fuqabâ' yang memahami naṣs secara literal hanya fokus pada satu aspek akan kehilangan aspek kontekstual dan semakin jauh dari semangat sharî‘ ah itu sendiri sehingga hukum Islam terkesan kaku dan menyulitkan. ${ }^{75}$ Menanggapi keenam poin yang ditulis al-Shâtibî di atas, Ibn 'Âshûr mengatakan "seorang mujtahid sangat perlu untuk mengetahui maqâsidal-shari'ah dari berbagai aspek secara komprehensif'. ${ }^{76}$

${ }^{73}$ Ibid., 27-28.

${ }^{74}$ Ibid.

${ }^{75}$ Ibn 'Âshûr, Maqậid al-Sharîa, 15-16.

${ }^{76}$ Kelima argumentasi al-Shâtibî di atas juga dikutip oleh Ibn 'Âshûr. Ia sepakat dengan al-Shâtibî bahwa semua ketentuan sharî‘ah pasti mengandung maqâsid, meskipun seringkali seorang mujtahid tidak mampu untuk mengungkapnya. Lihat Ibn 'Âshûr, Maqâsid al-Sharîah, 183-184. Jasser Auda juga sependapat dengan alShâtibî tentang kelima argumentasi di atas. Akan tetapi ia mengelaborasi dengan beberapa contoh kasus yang semuanya mengarah pada aplikasi maqâsid di ranah 
Masih berkaitan dengan pentingnya ilmu maqâssid al-sharîah terhadap efektivitas ijtihad, dalam makalah yang bertajuk "Maqâșid alSharî'ah According to al-Qarḍ̂âî in the Book 'al-Ḥalâl wa al-Ḥarâm fî al-Islâm", Basri bin Ibrahim al-Hasani al-Azhari mengatakan bahwa mempelajari ilmu maqậid adalah fard kifâyah. ${ }^{77}$ Lebih lanjut Basri merinci beberapa poin tentang pentingnya maqâsid bagi upaya dinamisasi hukum Islam, yaitu: (1) untuk menggali kebenaran kandungan al-Qur'ân secara komprehensif; (2) untuk bisa memahami hukum sharî‘ah dalam bingkai universalitas; (3) untuk memberikan spirit gerakan ijtihad; (4) sebagai sarana verifikasi terhadap produk ijtihad; dan (5) semakin memperkuat dan memberikan panduan dasar bagi para mufti terhadap berbagai persoalan umat yang kompleks. ${ }^{78}$

Tentang pentingnya maqâsid terhadap ijtihad, terdapat silang pendapat di kalangan ulama. Sebagai ilustrasi adalah tentang kebolehan pembayaran zakat dalam bentuk uang (bukan makanan pokok). Imâm Hạnafî memperbolehkan pembayaran zakat dalam bentuk uang yang senilai. Sedangkan Imâm al-Shâfíî (w. 204 H/820 M) tidak boleh dan harus dibayar dalam bentuk makanan pokok. Imâm Hanafí memahami bahwa fungsi utama zakat adalah untuk membantu fakir miskin sehingga zakat bisa dibayar dalam bentuk keduanya (uang atau bahan makanan pokok). ${ }^{79}$ Imâm Mâlik (w. 179 H/795 M) ketika ditanya tentang apa konsekuensi zakat mâl yang dibayarkan lebih awal (tidak pada akhir tahun), apakah ia masih punya kewajiban untuk membayar di akhir tahun atau sudah gugur kewajibannya. Kemudian Imâm Mâlik membuat analogi dengan seseorang yang melakukan salat sebelum waktunya, maka ia tetap berkewajiban untuk melakukan salat (mengulang) pada waktu yang semestinya.

yang lebih luas cakupannya. Penjelasan lebih lanjut bisa diihat dalam karyanya. Lihat Auda, Maqâsid al-Sharîah, 64-77.

${ }^{77}$ Pendapat ini sama dengan Jasser Auda yang mengatakan bahwa mempelajari ilmu maqâsid adalah wajib kifâyah (representative obligatory). Hal ini mengingat berbagai persoalan modernitas yang tidak cukup hanya merujuk pada bangunan fiqh klasik (al-fiqh al-taqlidîyah). Lihat Auda, Maqậsid al-Sharîah, 75.

${ }^{78}$ Basri bin Ibrahim al-Hasani al-Azhari, "Maqâșid al-Sharî́ah According to alQarḍ̂wî in the Book 'al-Ḥalâl wa al-Ḥarâm fî al-Islâm", International Journal of Business and Social Science, Vol. 2, No. 1 (Januari 2011), 240-241. Lihat juga Yûsuf alQarḍ̂âi, al-Ijtihâd fí al-Sharîah al-Islâmîyah (Kuwait: Dâr al-Qalam, 1996), 54-57.

${ }^{79}$ al-Raysûnî, Naz̧âriyyât al-Maqậisid, 336. 
Para fuqahâ' mazhab Mâlikî seperti Ibn 'Arabî (w. 543 H/1148 M) dan Ibn Rushd (w. 520 H/1126 M) tidak sependapat dengan gurunya. Mereka berpendapat bahwa meskipun dibayar sebelum akhir tahun, tetap sah. Mereka memberi dua argumentasi: (1) ada perpedaan antara zakat dan salat. Waktu salat telah ditentukan secara pasti sedangkan zakat tidak; (2) salat adalah ibadah mahzah (babl min Allâh) dengan ketentuan-ketentuan yang bersifat qat $\hat{\imath} \hat{\imath}$, sedangkan zakat lebih pada dimensi muamalah atau sosial yang memiliki kekuatan hukum zannî.

\section{Penutup}

Isu the closing of the gate of ijtihad cukup berdampak pada perkembangan hukum Islam terhitung sejak awal abad ke-10 Masehi. Beberapa sejarawan Muslim dan sarjana Barat terdapat silang pendapat tentang isu kontroversial itu. Menurut Wael B. Hallaq, kesaksian sejarah itu tidak benar. Beberapa sarjana Barat lainnya seperti W. Montgomery Watt dan Bernard Weiss berpendapat bahwa gagasan penutupan pintu ijtihad tidak memroyeksikan realitas sebenarnya, karena praktik ijtihad bukan hanya hak mutlak empat mazhab hukum yang ada tetapi juga hak bagi setiap Muslim yang telah memiliki kapabilitas yang memadai. Sedangkan para sarjana yang mengambil posisi tengah seperti Bernard Weiss, Edward Sell, Muhammad Ali, Muhammed Shâfîî, dan Ziya Gokalp berpendapat bahwa benar pintu ijtihad telah tertutup akan tetapi telah dibuka kembali seiring dengan kebutuhan dan berbagai persoalan baru yang mendesak untuk melakukan ijtihad.

Para tokoh maqââidiyyuñ seperti Ibn 'Âshûr, Tâhâ Jâbir al-'Alwânî, Aḥmad al-Raysûnî, Jamâl al-Dîn 'Aț̣iyah dan lain-lain juga sepakat bahwa hukum sharı̂‘ah (al-Qur'ân) selain memuat nilai-nilai juriyyât (parsial) juga mengandung nilai-nilai kulliyah (universal) yang seharusnya dipahami melalui pendekatan yang holistik (kullîyah) dalam aras kerangka berpikir maqâsid. Ibn 'Âshûr, sebagaimana al-Shâtibî, menegaskan bahwa pengetahuan tentang maqâsis sangat diperlukan untuk ijtihad dan segala bentuk manifestasinya. Fuqahâ' yang memahami nass secara literal hanya fokus pada satu aspek akan kehilangan aspek kontekstual dan semakin jauh dari semangat sharî‘ itu sendiri, sehingga hukum Islam terkesan kaku dan menyulitkan. Oleh karena itu, Ibn 'Âshûr menegaskan bahwa seorang mujtahid

${ }^{80}$ Ibid., 39, 336. 
sangat perlu untuk mengetahui maqâsid al-sharîah dari berbagai aspek secara komprehensif.

Masih berkaitan dengan pentingnya ilmu maqâsid al-sharîah terhadap efektivitas ijtihad, Basri bin Ibrahim al-Hasani al-Azhari mengatakan bahwa mempelajari ilmu maqâsid adalah fard kifâyah sebagai upaya dinamisasi hukum Islam, yaitu: (1) untuk menggali kebenaran kandungan al-Qur'ân secara komprehensif, (2) untuk bisa memahami hukum sharî‘ah dalam bingkai universalitas, (3) untuk memberikan spirit gerakan ijtihad, (4) sebagai sarana verifikasi terhadap produk ijtihad, dan (5) semakin memperkuat dan memberikan panduan dasar bagi para mufti terhadap berbagai persoalan umat yang kompleks.

\section{Daftar Rujukan}

Abadî, Fayrûz. al-Qâmûs al-Muhịt. Beirut: Muassasat al-Risâlah, 1987.

'Abd Allâh b. 'Abd Raḥmân al-Bassâmî, Tawdîh al-Aḥkâm min Bulùgh al-Marâm, Vol. 1. Makkah al-Mukarramah: Maktabat al-Asâdî, 2003.

Abû Mu'nas, Râid Naṣrî Jamîl. Manhaj al-Ta 'lì bi al-Ḥikmah wa Atharub fî Tashrî al-Islâm: Dirâsah Usûlìyah Taḅlinlîyah. Herndon: al-Ma‘had al-'Âlimî li al-Fikr al-Islâmî/IIIT, 2007.

'Affânî (al), Sayyid b. Husayn. Zahr al-Basâtîn min Mawâqif al-'Ulamâ' wa al-Rabbâniyyîn, Vol. 5. Kairo: Dâr al-'Affânî, t.th.

Ahmet, Akgündüz. Introduction to Islamic Law: Islamic Law in Theory and Practice. Rotterdam: IUR Press, 2010.

Âlûsî (al), Hussâm Muhy al-Dîn. Madkhal ilâ al-Falsafah. Beirut: alMuassasat al-'Arabîyah li al-Dirâsât wa al-Nashr al-Markâz alRaisî, 2005.

Âmidî (al), Sayf al-Dîn. al-Iḥkâm fî Usûul al-Aḥkâm, Vol. 4. Beirut: Dâr al-Kitâb al-'Arabî, 1984.

'Âshûr, Muhammad al-Ṭ̂hir b. Maqâsid al-Sharîab al-Islâmîyah, ed. Muhammad al-Tâhir al-Mîsâwî. Tunisia: Dâr al-Nafâis li al-Nashr wa al-Tawzî‘, 2001.

Auda, Jasser. Maqâsìd al-Sharîab: Dalîl li al-Mubtadi'. London: International Institute of Islamic Thought, 2008.

----. Maqâsid al-Sharíah as Philosophy of Islamic Law: A Systems Approach. London: International Institute of Islamic Thought, 2008.

Azhari (al), Basri bin Ibrahim al-Hasani. "Maqâșid al-Sharî‘ah According to al-Qarḍ̂âi in the Book 'al-Ḥalâl wa al-Ḥarâm fî al- 
Islâm", International Journal of Business and Social Science, Vol. 2, No. 1, Januari 2011.

Badâwî (al), Yûsuf Aḥmad Muhammad. Maqâsid al-Sharîah ind Ibn Taymîyah. Ardân: Dâr al-Nafâis li al-Nashr wa al-Tawzî‘, 1999.

Coulson, N.J. A History of Islamic Law. Edinburgh: Edinburgh University Press, 1964.

Fâsî (al), 'Allâl. Maqâsid al-Sharî́ah al-Islâmîyah wa Makârimuhâ. Beirut: Maktabat al-Wahdah al-'Arabîyah, 1963.

Ghazâlî (al), Abû Hâmid. al-Mustasfâ min Ilm al-Ușûl, Vol. 2. Kairo: Mațba'at Muștafâ Muhammed, 1973.

Hạâib, Kamâl. Taḥawnulât al-Ḥarakah al-Islâmîah wa al-Istirâjìyah alAmrikîyah. t.t.: Kutub 'Arabîyah, 2001.

Ḥalìm (al), Aḥmad b. 'Abd. Majmû' al-Fatâwâ li Shaykh al-Islâm Taqîy alDîn Ibn Taymîyah al-Harrânî, Vol. 9. t.t.: Dâr al-Wafâ' li al-Tịbâ'ah wa al-Nashr wa al-Tawzî́, 2005.

Hazm, Ibn. Al-Iḥkâm fì Usû́l al-Aḥkâm. Mesir: al-Aṣma, t.th.

Hallaq, Wael B. "Was the Gate of Ijtihâd Closed?", International Journal of Middle East Studies, 16, 1984.

Hourani, Albert. Arabic Thought in the Liberal Age 1798-1939. Cambridge: Cambridge University Press, 1983.

Ibrâhîm, Ḥannân Muhạmmad 'Abd al-Majîd. al-Taghayyur al-Ijtimâ î̀ fî al-Fiker al-Islâmî al-Ḥadîth: Dirâsat Taḅlìîyah Naqdîyah. Herndon, London: al-Ma'had al-'Âlamî li al-Fikr al-Islâmî, 2011.

Jabal, Muḥammad Hạan Ḥasan. Difấ 'an al-Qur'ân al-Karîm: Ușâlat alA'râb wa Dalâlatub 'alâ al-Ma'ânî fî al-Qur'ân al-Karîm wa al-Lughah al-'Arabîyah. Beirut: al-Tabâ'ah al-Hadîthah, 2000.

Kamâlî, Muhammad Hashîm. Principles of Islamic Jurisprudence. t.t.: Islamic Texts Society, 2003.

Karamali, Shaista P. Ali. "The Ijtihad Controversy", Arab Law Quarterly, Vol. 9, No. 3, 1994.

Kerr, Malcolm H. Islamic Reform: The Political and Legal Theories of Mubammad Abduh and Rashîd Ridâa. California: University of California Press, 1966.

Kesgin, Salih. "A Critical Analysis of the Schacht's Argument and Contemporary Debate on Legal Reasoning Throughout the History of Islamic Jurisprudence", The Journal of International Social Research, Vol. 4, No. 19, 2011. 
Khâdimî (al), Nûr al-Dîn Mukhtâr. Abḥâth fî Maqậid al-Sharî‘ah. Beirut: Muassasat al-Ma'ârif li al-Tibâ'ah wa al-Nashr, 2008.

Khâdimî, Nûr al-Dîn Mukhtâr. Abḥâth fî Maqâsìd al-Sharîab. Beirut: Muassasat al-Ma'ârif li al-Tabâ'ah wa al-Nashr, 2008.

Khalaf, 'Abd al-Wahhâb. 'Im Usûl al-Fiqh. Kairo: Dâr al-Quwaytîyah, 1968.

Liḥasâsanah, Aḥsan. al-Fiqh al-Maqâsid 'ind al-Imâm al-Shâtibî wa Atharub 'alâ Mabâhith Ușûl al-Tashrî́ al-Islâmî. Kairo: Dâr al-Salâm li al-Tibâ'ah wa al-Nashr wa al-Tawzî‘ wa al-Tarjamah, 2008.

Ma'luf, Louis. al-Munjid fì al-Lughah wa al-A lâm. Beirut: Dâr alMashrîq, 1986.

Musâwî, 'Abd al-Husayn Sharaf al-Dîn. al-Nașs wa al-Ijtihâd. Tehran: Qism al-Dirâsah al-Islâmîyah, 1985.

Qardâwî (al), Yûsuf. al-Ijtihâd fî al-Sharîah al-Islâmîyah. Kuwait: Dâr alQalam, 1996.

Raḥmân, Țâha 'Abd. Tajdìd al-Manbaj fì Taqwîm al-Turâth. Beirut: alMarkaz al-Thaqâfî al-'Arabî, 1994.

Rahman, Fazlur. "Post-Formative Developments in IsIam" dalam Islamic Studies. Karachi: Gateway Publications, 1966.

----. Islam. Chicago: University of Chicago, 1979.

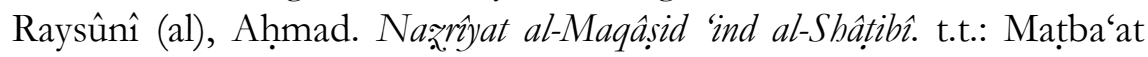
al-Najâh al-Jadîdah, 1991.

Schacht, Joseph. An Introduction to Islamic Law. Oxford: Oxford University Press, 1979.

Sell, Edward. The Faith in Islamic Law. London: t.p., 1896.

Shâfîî (al), Muhammad b. Idrîs. al-Risâlah fì Ușûl al-Fiqh, ed. Ahmad Muhammed Shakir. Kairo: Maṭba'at al-Musțafâ al-Bâb al-Ḥalabî, 1940.

Shah, Nias A. Islamic Law and the Law of Armed Conflict: The Armed Conflict in Pakistan. New York: Routledge, 2011.

Shalabî, Muhammad Muștafâ. Ta'lîl al-Aḥkâm. Mesir: t.p., 1974.

Shams al-Dîn, Muhammad Mahdî. Maqậsid al-Sharî‘ah. Damshiq: Dâr al-Fikr, 2001.

Shanqị̂̂i (al). Muḥammad al-Amîn b. Muhammad al-Mukhtâr al-Juknî. Mudhakekarah Usûul al-Fiqh 'alâ Radat al-Naz̧ir. Madinah: Maktabat al-'Ulûm wa al-Hikam, t.th.

Shâtịîi (al), Abû Ishââ. al-I'tisâm, Vol. 1, ed. Abû 'Ubaydah. t.t.: Maktabat al-Tawhîid, t.th. 
al-Muwâfaqât fî Ușûl al-Ạ̣kâm, Vol. 1, ed. Muhạmmad al-Khadar Husein al-Tûlisî. t.t.: Dâr al-Fikr, t.th.

al-Munâafaqât fî̀ Uș̂́l al-Aḥkâm, Vol. 2. Mesir: al-Maktabah alTijârîyah al-Kubrâ, t.th.

Shîrâzî, Abû Ishâaq. Kitâb al-Luma' fî Uṣ̂ul al-Fiqh. Kairo: Dâr alNadwah al-Islâmîyah, 1988.

Sulaymân b. Muhammad b. 'Abd Allâh al-Najrân, al-Mufâdalah fí alTbâdât: Qawâ'id wa Tatbîqât. Riyad: t.p., 2004.

Tahânawî (al), Muhammad 'Alî. Mawsû'ah Kashshâf Istilâhât al-Funûn wa al-Ulûm, Vol. 1, ed. 'Alî Dahrûj. Beirut: Maktabat Lubnân, 1996.

Zuhaylî (al), Wahbah. Ușûl al-Fiqh al-Islâmî,Vol. 2. Damaskus: Dâr alFikr, 1986. 